\title{
THE MANUMISSION OF SLAVES IN JUBILEE AND SABBATH YEARS
}

\author{
Michael A. Harbin
}

\begin{abstract}
Summary
Debt in the Old Testament economy was problematic, and our understanding of it is even more problematic, especially with respect to debt slavery. It is suggested that several common misunderstandings have contributed greatly to the problem. First, the Hebrew word 'ebed can be translated servant or slave and in the latter case it can denote both debt slave and chattel slave. In many cases there is a failure to make these distinctions. Second, there is a tendency to categorise all debt the same, regardless of the size. Third, a misunderstanding of the purpose of the jubilee has led to confusion regarding its role with respect to slavery and the manumission of slaves. Specifically, while the sabbath year guidelines included debt slavery, the jubilee by its nature did not involve slavery at all. Because the land 'sale' was really a land-lease, there was no debt involved, and the Israelite who 'sold' his land was not enslaved. It is then suggested that one option for the Israelite who 'bought' the land was to employ the 'seller' to work the land as a hired hand, which would explain the admonition that he was not be viewed as a slave.
\end{abstract}

\section{Introduction}

The issue of slavery in the Old Testament is complex. While slavery was at least condoned, various passages addressing servitude in general, especially with respect to the individual's release from servitude, seem contradictory. ${ }^{1}$ This leads to complicated explanations

1 Lester L. Grabbe, 'Leviticus' in The Pentateuch, ed. John Barton and John Muddiman (The Oxford Bible Commentary; Oxford: Oxford University Press, 2010): 149. 
as commentators struggle with different biblical texts that discuss the matter. For example, Kiuchi translates the last phrase of Leviticus 25:39, which addresses one aspect of Israelite servitude, as 'you shall not make him serve as a slave'. ${ }^{2}$ He then makes this puzzling comment: 'By definition, this Israelite becomes a slave, but the Lord sternly rules that such a person should not be treated as an ordinary slave' (italics added). ${ }^{3}$ In a similar manner, Rooker asserts that while a slave had the option of agreeing to stay with his master 'after six years of enslavement; in the Jubilee even that slave is set free'. ${ }^{4}$ If jubilee immediately followed a sabbath year as traditionally understood, this seems not only to contradict the sabbath manumission laws, but defeats the purpose of the continued service provision (economic security). ${ }^{5}$ As a result, commentators struggle to explain how these fit together.

An important aspect of the problem is the broad field of meaning for the Hebrew word, צִ עִברד ('ebed, plural 'abadim). Kaiser states 'the most basic idea of 'ebed is that of a slave'. ${ }^{6}$ However, more often it is understood as 'servant', and when it is translated 'slave' it covers two types. ${ }^{7}$ This ambiguity seems to have obscured differences between different 'ebed or servitude situations. ${ }^{8}$ These differences are especially evident when one compares the guidelines for the jubilee and sabbath years as set forth in Exodus 21, Leviticus 25 and Deuteronomy 15. While other passages address nuances of slavery in the nation of Israel, these three are the key passages which are understood to address the

2 Nobuyoshi Kiuchi, Leviticus (Apollos Old Testament Commentary vol. 3; Downers Grove, IL: IVP, 2007): 447.

3 Kiuchi, Leviticus, 462.

4 M. F. Rooker, Leviticus (Vol. 3A; electronic edn; Logos Library System; The New American Commentary; Nashville: Broadman \& Holman Publishers, 2001): 303-304.

5 The relationship between jubilee and the seventh sabbath year is problematic with a number of proposed solutions. However, most of the discussion on the relationship between the two has focused on the problem of two fallow years in a row. (See David L. Baker, Tight Fists or Open Hands? [Grand Rapids: Eerdmans, 2009]: 80-83 and Gregory C. Chirichigno, Debt-Slavery in Israel and the Ancient Near East, JSOTSup 141 [Sheffield: JSOT Press, 1993]: 303-313).

6 Walter C. Kaiser, 'עִבֶבד ('ebed)', TWOT 1553a.

7 Ringgren states, 'The subst. 'ebed refers to a person who is subordinated to someone else. This subordination can manifest itself in various ways, however, and 'ebed accordingly can have different meanings: slave, servant, subject, official, vassal, or "servant" or follower of a particular god' (Ringgren, 'עבד ('ebed)', TDOT, 10:387).

8 For example, while Klein begins with a clear distinction between slavery and servanthood, he assumes that all of the situations in the passages he addresses permit 'internal Israelite slavery' (Ralph W. Klein, 'A Liberated Lifestyle: Slaves and Servants in Biblical Perspective', CurTM 9, no. 4 [1982]: 214). 
limits of servitude and release, and are the focus of this study. In summary, the Exodus passage specifies 'ebed service for six years with release in the seventh. The Deuteronomy passage seems to identify that seventh year as the sabbath year. The Leviticus passage is more obscure, but seems to direct an additional release as part of the jubilee. ${ }^{9}$ Comparison of these passages raises three questions. First, do the three passages address the same situations (i.e. do they all reflect slaveryand if so, is it the same kind)? Second, was the seventh year release (commonly termed manumission ${ }^{10}$ ) addressed in Exodus intended to occur during the seventh year of servitude or the seventh year of the sabbath year cycle? Third, how does one reconcile sabbath year manumission with jubilee year manumission?

The questions are not new, but proposed answers have varied widely and generally end up with less than satisfactory results especially with respect to jubilee. Presently, we are not able to review all of the different proposals, but will note two recent studies which make positive advances in distinguishing between jubilee and sabbath manumission. Chirichigno has provided an excellent overview of the discussion. Drawing on the distinction between debt and chattel slavery, he concludes that all three situations reflect a form of debt slavery, but that the 'ebed service in the Leviticus 25 passage differs from the other two, apparently because land is involved. ${ }^{11}$ Baker picks up on this distinction, although he prefers the term 'temporary slaves' for the Exodus and Deuteronomy situations, and 'bonded labourers' for the Leviticus situation. Advancing the idea of land involvement, he suggests that Leviticus 25 addresses a landholder as opposed to the other two situations where a landless person is in view. ${ }^{12}$ While both have made cogent observations regarding the distinctions, as will be shown below, they also misconstrue the nature of jubilee as presented in the Leviticus text, as well as the debt issues.

In the broader discussion several factors underlie the debate. First, as noted above, the ambiguity of the Hebrew word 'ebed has obscured the distinctions between the different types of servitude, which seems most evident in the commentaries. Second, the broad pattern seems to

9 So Chirichigno, Debt-Slavery, 186, 256, 302.

10 For example, see Chirichigno, Debt-Slavery, 186-343.

11 Chirichigno, Debt-Slavery, 353. However, he also claims that the Lev. 25 service is 'not really debt-slavery at all' (336).

12 Baker, Tight Fists or Open Hands?, 170-73. 
view debt as debt regardless of the size. ${ }^{13}$ As a result the representation is that the consequences are the same whether the debt was a shekel or a talent. Third, there is confusion regarding the purposes of both the sabbath and jubilee years with respect to servitude. While all three affect the issue of manumission, we will begin with the issue of servitude.

\section{The Concept of Slavery in Israel}

Not only was the Hebrew term 'ebed used for both servant and slave, ${ }^{14}$ it also denoted two types of slaves. Chirichigno categorises them as debt slaves and chattel slaves, which is a good distinction. Chattel slaves were individuals who 'were regarded as the property of their owners'. ${ }^{15}$ Their servitude was for life unless manumitted. In the Ancient Near East, chattel slaves could be individuals who had been captured in war, kidnapped, or who had actually been born into a slave situation. ${ }^{16}$ They could be bought and sold, and in general had few rights. ${ }^{17}$ Israelite law (whether observed or not) limited chattel slavery to non-Israelites (Lev. 25:44), prohibited kidnapping (Exod. 21:16), and overall set forth more humane standards of treatment. ${ }^{18}$

In contrast, Chirichigno defines debt slavery as a situation where a "creditor has only purchased the service or capacity for work (Arbeitskraft)' of the individual. ${ }^{19}$ Basically, debt slaves were individuals who entered servitude as a result of a debt which they were unable to repay, and they worked off their debt. Indentured servitude might be a more modern correspondence. As such, their servitude was temporary with a fixed termination point, and in general they had some rights.

Since Hebrew uses the same term, 'ebed, for both categories of slavery as well as other types of servitude, careful evaluation of the

\footnotetext{
13 See, for example, Chirichigno, Debt-Slavery, 225.

14 Klein, 'Liberated Lifestyle', 212.

15 Chirichigno, Debt-Slavery, 145-47.

16 Baker, Tight Fists or Open Hands?, 113.

17 Mooney argues that this type of slave had no more rights than 'any other piece of property' in the ANE (Jeffrey D. Mooney, 'Israel in Slavery and Slavery in Israel', SBJT 12 no.3 [2008]: 71).

18 Baker, Tight Fists or Open Hands?, 116-21.

19 Chirichigno, Debt-Slavery, 145.
} 
situation is necessary to determine the type of servitude intended. ${ }^{20}$ For example, Chirichigno correctly categorises the servitude associated with the sabbath year (addressed in Exod. 21 and Deut. 15) as debt slavery, as indicated by the clearly limited term of servitude. His evaluation of the jubilee situation in Leviticus 25, however, is problematic. He characterises the subject individual as also being a debt slave, apparently based on the assumption that the phrase translated as 'he sells himself to you' (Lev. 25:39 NASB) ${ }^{21}$ suggests that he is selling himself into slavery. ${ }^{22}$ In contrast, Milgrom maintains that all that is being sold is labour. He states 'The Israelite can, therefore, never become a slave ... his status is that of a śākîr, a wageearning day laborer (italics added). ${ }^{23}$ This is based on the next verse (Lev. 25:40) which strongly asserts that any individual subject to the jubilee criteria was to be viewed as a 'hired man'. Further, Leviticus 25:39 goes on to state specifically regarding the one who 'sold himself': 'you shall not subject him to a slave's service' (italics added). ${ }^{24}$

As will be seen below, it would appear that the reason for this distinction is that the circumstances surrounding the jubilee situation in Leviticus 25 are of a different nature from those of a sabbath year. These differing circumstances explain why the Leviticus 25 service is terminated in the jubilee year, as opposed to the sabbath year.

\section{3. 'Debt Slaves' in Israel}

The initial directives on freeing slaves as given in Exodus are in the literary context of the 'nation' of Israel receiving the Law while at Sinai. Within that context, Israel is represented as having just emerged from a slavery situation three months earlier (Exod. 13:3, 14; 20:2). As such, it is unlikely that the text was intended to address a situation in

20 H. Ringgren, 'עבד', 10:387; Chirichigno, Debt-Slavery, 142. Klein suggests that while the OT uses the one term, context differentiates between slave with negative connotations and servant with positive (212).

21 All Scripture quotations are from the NASB unless otherwise noted.

22 Chirichigno, Debt-Slavery, 145-48.

23 Jacob Milgrom, Leviticus 23-27 (The Anchor Bible; New York: Doubleday, 2001): 2163.

24 Chirichigno (329) argues that the service here is to be distinguished from that of a chattel slave, which Leviticus addresses later in the chapter, but this seems to be a forced distinction. 
existence at that time. First, the text describes the Israelites as having 'plundered the Egyptians' (Exod. 12:36) giving a picture of people possessing tangible assets. However, the text further presents a picture that their physical needs were being met in a unique way as God provided water (either directly as in Exod. 15:25, or by showing the nation existing springs as in Exod. 15:27), bread or manna (Exod. 16:4) and meat (Exod. 16:8). As such there would have been no contextual reason to borrow money, and consequently no debt slavery. So, while the situation in Exodus 21 is undoubtedly debt slavery, it is being presented as an anticipated future contingency for after the nation entered the land.

The Deuteronomy 15 guidelines for freeing slaves reflect a similar situation, although two key differences exist. ${ }^{25}$ First, the literary context places the nation approximately forty years after Sinai in the Transjordan, poised to enter the land. Other than that, the economic situation would have been the same. Second, the Deuteronomy 15 guidelines amplify those of Exodus 21. As Baker expresses it, 'it is probable that the Deuteronomic Law is a deliberate revision and expansion of this predecessor [Exodus]'. ${ }^{26}$ He suggests that one such revision is tying the manumission of debt slaves to the sabbath year. ${ }^{27}$ Again, debt slavery is presented as something anticipated in the future and it is that future context at which we need to look.

Two factors are important. First is the incurring of debt. Second is the transition from debt to debt slavery. From our perspective it is difficult to envision an economy which is not critically dependent upon cash flow and credit. However, recent studies have shown that while the typical Israelite family lived a rather Spartan life, it was one that was largely self-contained. ${ }^{28}$ Israel, like much of the Ancient Near East practised a combination of village based farming and pastoralism which King and Stager define as agropastoralism (as opposed to

25 Chirichigno asserts that scholars 'agree unanimously that the manumission law in Deut. 15:12-18 is based upon the manumission law in Exod. 21:2-6' (Chirichigno, Debt-Slavery, 256).

26 Baker, Tight Fists or Open Hands?, 166.

27 Baker, Tight Fists or Open Hands?, 278-80.

28 See David C. Hopkins, The Highlands of Canaan (Sheffield: Almond Press, 1985); Philip J. King and Lawrence E. Stager, Life in Biblical Israel (Louisville: Westminster John Knox Press, 2001); and Oded Borowski, Agriculture in Iron Age Israel (Winona Lake, IN: Eisenbrauns, 2009). 
transhumant pastoralism). ${ }^{29}$ As they put it, 'In an agropastoralist economy, such as ancient Israel had for most of its duration, the majority of economic activity took place within households, great and small ... the household was designed to maintain its own economic survival, even if only at a minimal level. ${ }^{30}$ That is, the extended family largely grew or made almost everything that it used. As history progressed, the economy grew more complex as skilled craftsmen began to specialise. Even then, barter was the norm. ${ }^{31}$

Described as a subsistence economy, it would be a situation where little cash was required. To put it in modern terms, they would have had no house payments, no property taxes, no utility bills, and no insurance costs. Most foods would have been grown in the family fields, the garden, or within their flocks and herds. Even seed would have been saved from year to year. ${ }^{32}$ Food, including such mainstays as bread, was cooked at home. Transportation was normally on foot. So, there were few food or transportation costs. The 'commute to work' would have involved the walk to the field. ${ }^{33}$ Beyond that people seldom left the village area. While some household items such as clothing, cooking and eating utensils, farming utensils, and furniture, could be 'outsourced', normally even these would be produced at home. ${ }^{34}$ The point is that on a daily basis, the average rural Israelite did not have a cash flow problem necessitating credit.

So then, what would cause debt leading in some cases to debt slavery? While actual factors are matters of conjecture, given the environment, crop failure surely ranks high on the list. However, Hopkins notes several 'concrete expressions of the attention paid to

\footnotetext{
29 King and Stager, Life in Biblical Israel, 112.

30 King and Stager, Life in Biblical Israel, 192.

31 King and Stager, Life in Biblical Israel, 112.

32 Contra Wenham (Gordon J. Wenham, The Book of Leviticus [New International Commentary on the Old Testament; Grand Rapids: Eerdmans, 1979]: 322), and Westbrook and Wells (Raymond Westbrook and Bruce Wells, Everyday Law in Biblical Israel: An Introduction [Louisville: Westminster-John Knox, 2009]: 119). Most farmers through history saved some of their crop from one year to provide seed for the next year's crop. Buying 'seed corn' did not become a practice until the modern development of hybrids. According to the Institute of Science in Society, this was as late as the 1920s ('Hybrid Seed', ISIS Report 2 September 2005, http:// www.isis.org.uk/hybridSeed.php, downloaded 22 August 2011).

33 Hopkins suggests that the workable area for a household or village would have been a 'radius of $5 \mathrm{~km}$ for grain ... and two hours' walk for herds' (131).

34 The furnishings of the typical Israelite household would have been very basic by our standards (see King and Stager, Life in Biblical Israel, esp. pp. 12-21).
} 
storing produce from a year of plenty to provide for a year of farming failure' including storage buildings, grain-pits, and collared-rim pithoi (a type of storage jar). ${ }^{35} \mathrm{He}$ indicates that these preparations would also support a general fallow year (i.e. a sabbath year). ${ }^{36}$ In these cases, the lack of harvest would have been community wide not individual.

More localised situations which would lead to an individual or a single family going into debt might include household disasters such as the incapacitation or death of a key family member, or the loss of a critical capital asset such as an ox or donkey or even an essential farm implement. ${ }^{37}$ These different losses would affect a household in various ways.

The loss of a key family member would be a major hurdle since manpower was the main resource for economic survival in a labour intensive agricultural society. ${ }^{38}$ The keystone was the male 'head of the household' so that the loss of the husband left the wife and children in an extremely difficult situation, as seen in Ruth 1. The scope of the difficulty would vary depending on factors such as the ages of the couple and the number, if any, of children and their ages. Methods of alleviating this loss included remarriage (including levirate marriage), or turning to gleaning as a form of welfare provision. Another alternative for individuals possessing greater assets might be to hire labourers to perform the critical tasks. This last alternative might also be an option in the case of a temporary incapacitation. Still, in these situations, the financial strains would be tremendous.

Not as devastating, but a major financial hurdle would be the loss of a farm animal. Borowski indicates that the key agricultural tasks performed by animals were ploughing and threshing. Both were normally done by pairs of oxen or donkeys, and both directly affected how much land could be put into production. ${ }^{39}$ The price of animals is difficult to establish not only from a lack of documentation but also due

35 Hopkins, Highlands of Canaan, 268.

36 Hopkins, Highlands of Canaan, 200-202.

37 Sider very clearly points this out when he discusses capital (Ronald J. Sider, Just Generosity [Grand Rapids: Baker Book House, 2007]: 76). What is not clear is the concept of 'capital'. Sider calls the land 'capital' and limits capital to that commodity (75-76). Others include items such as seed, farm implements, etc., as capital (Paul Erdkamp, 'Agriculture, Underemployment, and the Cost of Rural Labour in the Roman World', $C Q$ n.s. 49 no.2 [1999]: 561).

38 Hopkins, Highlands of Canaan, 232-35.

39 Borowski, Agriculture, 51-52 and 63-65. 
to price fluctuations. Throughout the Old Testament, references to animal sales are vague suggesting market value as a variable (e.g. Exod. 21:35). Still Dubberstein maintains that in Babylon at the time of Hammurabi, 'a good ox was valued at twenty shekels and fifteen hundred years later the price had not changed much'. ${ }^{40}$ This will be used as a working figure.

First Samuel 13:20-21 lists farm implements including ploughs, mattocks, axes, forks, and hoes. Even 'complex' implements such as ploughs were surprisingly simple in design. They consisted of a wood frame with a single plough point, made either of bronze or iron. ${ }^{41}$ The 1 Samuel passage states that for iron implements, the Israelites had to utilise Philistine blacksmiths for sharpening or repair, and the price was about two thirds of a shekel. ${ }^{42}$ The price of replacement tool heads is unknown.

With these situations, we can build a rough scale of debt. On the bottom end, we could conjecture the emergency repair of a critical tool - two thirds of a shekel, approximately a month's wages for a hired hand. ${ }^{43}$ At the higher end, we see the replacement of work animals, at an approximate cost of twenty shekels (or more if a full team needed to be replaced). The lower end might represent an amount that a farmer might reasonably expect to recuperate in a good harvest. At the other end, the amount could require several years to make up. It is in that context that we must place the 'slavery' (specifically debt slavery) which is addressed in the stipulations of the sabbath year.

40 Waldo H. Dubberstein, 'Comparative Prices in Later Babylonia (625-400 B.C.)', The American Journal of Semitic Languages and Literatures 56:1 (1939): 30. Similarly, Farber looking at Northern Babylonia cites a 'mean price of 9 shekels, but observes that was a "significant decline" from earlier prices of thirty shekels' (Howard Farber, "A Price and Wage Study for Northern Babylonia during the Old Babylonian Period', Journal of the Economic and Social History of the Orient 21:1 (1978):15-16.

41 Borowski, Agriculture, 49.

42 Bergen includes repairs as an option then comments, 'No doubt this fee was considered outrageous and had the effect of oppressing Israel economically as well' [R. D. Bergen, 1, 2 Samuel (The New American Commentary Vol. 7; electronic ed., Logos Library System; Nashville: Broadman \& Holman Publishers, 2001]: 154).

43 This assumes that there was a rough equivalency between the wages in Mesopotamia and those in Israel. Nemet-Nejat concludes that in Babylon, a hired hand earned 10 shekels a year (Karen Rhea Nemet-Nejat, Daily Life in Mesopotamia [Peabody, MS: Hendrickson, 2002]: 257). This correlates well with Chirichigno's spread of 6-14 shekels per year, depending on the source and the historical period (Chirichigno, Debt-Slavery, 225). 


\section{The Purpose of Sabbath and Jubilee Years}

While the canonical text presents several differences between sabbath and jubilee years, there are some commonalities, primarily letting the land rest. The first reference to the sabbath year states that the nation was to 'let [the land] rest and lie fallow' (Exod. 23:10-12), although both here and elsewhere other purposes are added. Underlying all of these seemed to be a basic purpose that the nation show trust in God for its provision as indicated by the phrases, 'a Sabbath to the Lord' in Leviticus 25:2-7 and 'the Lord your God shall bless you' in Deuteronomy 15:9-11.

The issue of the fallow year has long been a major point of discussion. The idea of skipping a year of farming is difficult to grasp, especially within an agrarian economy where one's life depended on a successful harvest, and where modern methods of food preservation were not available. That a single harvest on a subsistence farm would see a family through two years to cover a sabbath year has proven so difficult that various proposals have been offered to lessen the tension including arguing that there was a rotation among farmers each year so that only certain farms were fallow at any specific time, ${ }^{44}$ suggesting that each individual farmer would let one portion (one seventh) of his land lay fallow each year, ${ }^{45}$ and concluding that the concept was really just an ideal never practised. ${ }^{46}$

Hopkins and subsequently Milgrom actually argue for a biennial rotation where a landowner would crop and fallow half of his land each year, switching back and forth, with both halves being fallowed in the sabbath year. It is suggested that this would be a workable process. ${ }^{47}$

Although its exact nature is debated, many scholars now accept the idea that a sabbatical year was expected, based on extra biblical sources and analogous concepts in other areas of the ancient world. ${ }^{48}$ Still,

\footnotetext{
44 Christopher J. H. Wright, 'What Happened Every Seven Years: Part I', Evangelical Quarterly 56:3 (1984):130-131.

45 Borowski, Agriculture, 144-45.

46 Eli Ginzberg, 'Studies in the Economics of the Bible', JQR n.s. 22 no. 4 (1932):

362; and Robert Gnuse, 'Jubilee Legislation in Leviticus: Israel's Vision of Social Reform', BTB 15 (1985): 43-44.

47 Hopkins, Highlands of Canaan, 200-202 and adapted by Milgrom, Leviticus 23-27, 2246-49.

48 Lee W. Casperson, 'Sabbatical, Jubilee, and the Temple of Solomon', VT 53 (2003): 283-85.
} 
while it may be that the nation as a whole never practised it, ${ }^{49}$ that sidesteps whether there was an authoritative expectation that it be done, and the conclusion is that the expectation was there. ${ }^{50}$

While land rest was also a purpose of the year of jubilee, according to Leviticus 25:10 the primary purpose was that it was 'a year of release' where Israelites were to return to their family property. Land rest seems to be secondary but is specifically directed in Leviticus $25: 11$. This produces problems, especially in terms of the relationship between the seventh sabbath year and jubilee, years 49 and 50 respectively. If one fallow year is difficult to accept, two in a row is virtually unbelievable. These difficulties have led to various suggestions such as it was an exilic ideal never instituted,,${ }^{51}$ or it was really a short (intercalary) year of forty-nine days added during the seventh month of the forty-ninth year, ${ }^{52}$ or that it was identical with the seventh sabbath year..$^{53}$ While an evaluation of these alternatives is beyond the scope of this study, Milgrom seems to be correct when he concludes that although there were problems, jubilee was indeed the fiftieth year subsequent to the seventh sabbath year and observes: 'the fertility required for the land to produce crops that will feed the nation for three years is not answered by a rationalistic compromise, but is due solely to divine grace'. ${ }^{54}$

While the sabbath year and the jubilee year had the issue of land rest in common, there were also significant differences. A major difference is the issue of slave manumission.

\section{Servitude and the Sabbath Year}

The sabbath year (or seventh year) had at least a fivefold purpose. As noted, the first was to let the land rest which is tied conceptually to the

\footnotetext{
49 The Chronicler records Jeremiah as admonishing the nation that one reason for the exile was to give the land its sabbath rest (2 Chron. 36:21).

50 Milgrom, Leviticus 23-27, 2245-48.

51 Roland de Vaux, Ancient Israel (New York: McGraw Hill, 1965): 175-76.

52 Sidney. B. Hoenig, 'Sabbatical Years and the Year of Jubilee', JQR 59 (1969): 222-36 and Wenham, Leviticus, 319.

53 John E. Hartley, Leviticus (WBC 4; Dallas: Words Books, 1992): 435-36.

54 Milgrom, Leviticus 23-27, 2250.
} 
sabbath day given as a day of rest (Exod. 23:12). ${ }^{55}$ The Exodus passage also suggests that a reason for the rest was to help provide for the poor: 'so that the needy of your people may eat'. ${ }^{56}$ The third purpose of the sabbath year really had little to do with the land - this was a remission of debts. Deuteronomy 15:1-11 addresses this purpose and states explicitly that in the seventh year, 'every creditor shall release what he has loaned to his neighbor'. Tied into this was the fourth purpose, the directive to free 'abadim, who are understood to be debt slaves. ${ }^{57}$ The fifth purpose of the sabbath year, although not stated explicitly in these terms, was to test the faith of the people. The Deuteronomy passage states that the nation would prosper 'if only you listen obediently to the voice of the Lord your God, to observe carefully all this command which I am commanding you today' (Deut. 15:5).

Of these five, the first and last seem to have been most important. Leviticus 26:33-35 warned the nation that if it did not observe the sabbath years, God would scatter it throughout the other nations so the land could rest. In 2 Chronicles $36: 21$, Jeremiah is cited as having declared that the exile had occurred for that purpose. Because the nation did not trust God nor allowed the land to rest, it was expelled from the land. It then appears that purposes two through four (providing for the poor, forgiving debts, and freeing 'abadim) derived from anticipation that the nation would not adhere to the sabbath year guidelines..$^{58}$

55 For example, see Nahum M. Sarna, Exodus (The JPS Torah Commentary; Philadelphia: The Jewish Publication Society, 1991): 144 and John I. Durham, Exodus (WBC vol. 3; Waco: Word Books, 1987): 331.

56 While provision for the poor is given as a reason to let the land rest, it would seem that this was not the primary purpose since this would result in extra food only one in seven years, and other provisions were made for helping the poor in non-sabbatical years.

57 Chirichigno, Debt-Slavery, 185.

58 The Deuteronomy passage reports that God promised the generation about to enter the land that if they obeyed God, there would be no poor in the land (Deut. 15:4-5). A few verses later, however, the assertion is made that there would always be poor (Deut. 15:11). Rather than a contradiction, it seems to be a contrast between the ideal and the projected reality. Merrill suggests that the first statement is an observation on the part of Moses that the nation ought not to experience poverty in the rich land of Canaan (Eugene H. Merrill, Deuteronomy [The New American Commentary, Vol. 4; Nashville: Broadman \& Holman Publishers, 1994; electronic edn; Logos Library System, 2001]: 244). However, it seems rather to be God's acknowledgement that he knew the nation would never follow his guidelines. If that is the case, then one implication is that a primary source of poverty is disobedience to God's guidelines. 
Our focus, however, is on the remission of debt and the freeing of the debt slaves. While both reflect provision for the poor, there is much confusion about what was actually involved. For example, Chirichigno addresses economic issues by comparing the value of a debt slave as opposed to a chattel slave. He maintains that the cost of a debt slave was thirty-five shekels for a male. ${ }^{59}$ But this assumes both that debt slaves were 'bought' for a fixed price and that all debt slaves served for the same period of time, six years - regardless of the amount of debt. It also seems to assume that the only way an Israelite was able to borrow money was to 'sell' himself into debt slavery. All are unwarranted assumptions. If the seventh year was the sabbath year, then all debt slaves would be released regardless of how long they had served. Thus, the maximum length of service would be six years. ${ }^{60}$ As Wenham argues that the length of the period of service would vary with the amount of debt. This also suggests that a debt could be paid off before the sabbath year arrived. ${ }^{61}$ This is more likely since it highlights the main point of the debt, which was to get the debtor through a hard time.

A possible scenario might be that a farmer broke a critical farm implement, such as a plough, during planting season. He lacked the funds (two-thirds of a shekel) to get it repaired, and went to a neighbour for a loan. While repayment terms are not addressed, it would be expected that under these circumstances the loan period would have been relatively short, perhaps as soon as the next harvest. If so, 'debt slavery' would then likely not have occurred until the expected repayment time came and the individual was not able to repay because of further adverse circumstances. ${ }^{62}$ It is also possible that debt slavery was a voluntary alternative method of repaying the debt under

59 Based on Babylonian data, he calculates that a debt slave there would take three years to pay off his debt, but that an Israelite's slave would need to work twice that long. This assumes that the debt to be worked off is the same in all cases (Chirichigno, Debt-Slavery, 225).

60 Sarna cites Rabbinic tradition making this the seventh year after the indentureship began, although he cites Targum Jonathan as representing 'an earlier stratum' which interprets the seventh year as the sabbath year (Sarna, Exodus, 118).

61 As Wenham puts it, it is similar to 'enabling a man who could not pay a fine to work off his debt directly' (Wenham, Leviticus, 322). This is a good analogy which illustrates an important point which in general seems to be overlooked - that is, the debt was finite, and could be paid off through labour. As such, there should be a correlation with the amount of labour and the amount of debt.

62 So Craigie, although he argues for a fixed six years of servitude regardless of the size of the debt 'defaulted' on (Peter C. Craigie, The Book of Deuteronomy [NICOT; Grand Rapids: Eerdmans, 1976]: 238). 
specific circumstances such as a larger loan, i.e. one that required several harvests to repay.

Our suggestion then is that the debt involved in sabbath year debt (and subsequent debt slavery) was relatively small. Lowery insightfully labels this debt 'subsistence debt', which would be a loan designed to help a kinsman or neighbour in a difficult time. ${ }^{63}$ Thus, subsistence debt would be money borrowed with expectations that the borrower could repay it after a harvest or two without going into debt slavery. Several indicators suggest this. In both Exodus and Deuteronomy, the borrower is characterised as a poor man, and in that status likely would not be borrowing large amounts. While collateral was allowed, the examples used are relatively small (a cloak in Exod. 22:26, and by implication, shoes in Amos 1:6) suggesting that the loan was small. Also, the collateral was portable and was to be returned when needed (in the case of the cloak before sunset of the day borrowed). This is amplified in Deuteronomy 24:10-13 which mandates that the lender did not have the right to enter the borrower's house to secure the pledge. For these loans the lender was not to charge interest.

Further, if the loan was not repaid by the sabbath year it was to be forgiven (Deut. 15:1), which means that the amount of the loan was small enough that the lender was reasonably able to write off the loss. ${ }^{64}$ Even so, Deuteronomy 15:9 also warns against reluctance to lend because the sabbath year was near. ${ }^{65}$

Complicating the directive that the debt was to be forgiven in the seventh year (if it had not been repaid) is the subsequent statement that debt slaves were to be freed in the seventh year (Deut. 15:12). Craigie argues that this would not be the sabbath year but after an actual six

63 Lowery draws this distinction from the fact that while interest could be charged for loans to foreigners (Deut. 23:19-20) interest was forbidden on loans to fellow Israelites and concludes that they represent two different types of loan. While he calls the loans to fellow Israelites 'subsistence loans', he suggests that the loans to foreigners are 'trade loans' i.e. loans for business purposes (Richard H. Lowery, Sabbath and Jubilee [St. Louis: Chalice Press, 2000]: 40).

64 So Merrill, Deuteronomy, 243. If these laws originated during the Mosaic period (cf. Robert North, Sociology of the Biblical Jubilee [Rome: Pontifical Biblical Institute: 1954]: 192-212) it is unlikely that the lender was very much better off than the debtor. As Chirichigno notes, socio-economic stratification seems to have developed later (Chirichigno, Debt-Slavery, 139-42).

65 For this reason, Merrill suggests that the size of the loans would decrease as one drew closer to the sabbath year (Merrill, Deuteronomy, 243). However, if these were subsistence loans that would be expected to be repaid after a harvest a decrease in size would not be necessary. 
year period of labour, which creates several problems. ${ }^{66}$ It would require that the term 'seventh year' carry a different connotation here than in Exodus 23:11 and Deuteronomy 15:1 where 'seventh year' seems clearly to refer to the sabbath year. ${ }^{67}$ It also mandates a fixed six year period of servitude regardless of the amount of debt.

A better understanding is that the Israelite would go into 'debt slavery' in order to pay off his debt with a correlation between the value of the labour and the debt. This fits Wenham's suggestion that the period of servitude varied with the amount of debt, and would suggest that the six years of labour specified in Exodus 21:2 was not an absolute term of service, but a maximum. ${ }^{68}$ An analogy to this might be the 'eye for eye' restriction in the same chapter (Exod. 21:24-25) which is deemed by some scholars as setting a limit on retaliation rather than setting up a mandatory retribution. ${ }^{69}$ If this was the case, then a better translation than 'debt slavery' would be warranted-perhaps 'indentured servanthood' would be more appropriate. In either case, under this understanding, if the debt had not been repaid by the next sabbath year, it was to be forgiven.

Within the overall economic structure of early Israel it would then seem that when an Israelite had to borrow a small sum, he had several options for fulfilling his obligation. First, he could repay the debt within a reasonable period, probably by continuing to farm (or practising his regular trade). An alternative not discussed might be for a relative (go'el or 'kinsman redeemer') to assist him, although that raises questions regarding the role of the extended family which are

66 Craigie, Deuteronomy, 238.

67 For example, see Sarna, Exodus, 144; Brevard S. Childs, The Book of Exodus: A Critical, Theological Commentary (Philadelphia: The Westminster Press, 1974): 482; Gerhard von Rad, Deuteronomy: A Commentary (Philadelphia: The Westminster Press, 1966): 105.

68 Sarna calls it a maximum limit but allows for a shortening only in the case of a jubilee year (Sarna, Exodus, 119). In general, commentators seem to understand these six years as a fixed period meaning that the length of servitude was the same, regardless of the amount of debt. (For example, see Durham, Exodus, 321; and Martin Noth, Exodus: A Commentary [Old Testament Commentary Series; Philadelphia: Westminster Press, 1962]: 176).

69 George Rawlinson, 'Exodus' in The Pulpit Commentary, ed. H. D. M. Spence Jones (vol. 2; New York: Funk and Wagnells, n.d.; electronic edition, Bellingham WA: Logos Research Systems, Inc., 2004): 180. See also John D. Hannah, 'Exodus' in The Bible Knowledge Commentary: An Exposition of the Scriptures, ed. John F. Walvoord, and Roy B. Zuck (Wheaton, IL: Victor Books, 1983-1985): 1:142. Taking a different approach, Sarna argues from Rabbinic tradition that the reference denotes 'monetary payment and not physical retaliation' (Sarna, Exodus, 126). 
beyond this study. Should circumstances prevent repayment by the sabbath year, the debt would be remitted. An alternative in the interim would be debt slavery for either the borrower or a member of his family with the labour providing repayment. ${ }^{70}$ If the labour proved inadequate to repay the debt by the sabbath year, the debt slave was manumitted. In this understanding, then, the debt slavery cited in Exodus and Deuteronomy was a servitude designed to allow a borrower to pay back relatively small debt through labour. ${ }^{71}$

\section{Jubilee}

In contrast to the sabbath year, jubilee is presented as a 'consecrated year' following the seven sabbath year cycle and is only described in Leviticus 25:8-55. ${ }^{72}$ As noted, the exact nature of this 'year' is debated, although Leviticus $25: 10$ calls it 'the fiftieth year'. Thus it seems the most likely understanding of the text is a full year after the seventh sabbath year. ${ }^{73}$ While the land was to rest as in a sabbath year, the focus of jubilee was related to the land which had been 'sold'. Specifically, all agricultural land which had been given as part of the national inheritance and had been 'sold' was to revert to the family to which it had been given. ${ }^{74}$

70 Exodus 21:7 suggests that this servitude could be performed by the individual, or by a member of his family, although that raises other issues, such as the case of a female, which are beyond the scope of this study.

71 One other factor is the option that the debt slave (or indentured servant) had at the end of his service and that would be to voluntarily remain in a service relationship with his master (Exod. 21:5-6, Deut. 15:16), but that is beyond the scope of this study.

72 Two other passages mention the year in terms of specific qualifications regarding it. Lev. 27:16-21 addresses the case of a person who dedicates a field to God establishing the value in terms of the redemption time before jubilee. Num. 36:1-9 addresses the case of the daughters of Zelophehad as they inherit the land of their father to ensure that the land remained with the tribe of Manasseh, not with their husbands' families or tribes in subsequent years of jubilee.

73 Maimonides, Hilchot Shemitah V'Yovel 10:7, tr. by Eliyahu Touger, Mishneh Torah Sefer Zeraim (Jerusalem: Moznaim Publishing Corp, 2005): 810; Baruch A. Levine, Leviticus (The JPS Torah Commentary; Philadelphia: The Jewish Publication Society, 1989; electronic edition; Skokie, IL: Varda Books, 2004): 130; Milgrom, Leviticus 23-27, 2163.

74 The fact that Leviticus 25 addresses only the agricultural land which had been divided among the tribes at the time of the conquest, which according to Lev. 25:23 was not to be sold permanently seems significant. At a minimum it seems to omit land which the nation acquired later, although that is beyond the scope of the present study. 
As presented, the situation would involve a property owner who needed significant financial assistance following a major setback such as replacing the loss of a critical farm animal. A regular loan as discussed above would be inadequate since it was unlikely that the borrower would be able to repay the loan before the next sabbath year. This provides another option-he could 'sell' his only adequate asset, the land which he had inherited. But according to Leviticus 25:15-16 the land was not sold. As described, what were being sold were the crops that the land would produce for a period of time up to the next jubilee. Consequently, it would be more correct to say that the land was leased with the lease rate being based on the number of years of crops until the next jubilee. ${ }^{75}$ Failure to note this distinction has led to serious confusion. For example, assuming actual land sales and addressing the land return, Carmichael states 'we can only imagine the enormous upheaval that would result'. ${ }^{76}$ But if the individual 'buying' the land was aware that he was only buying the crops (i.e. leasing the land), there would be no more economic upheaval than occurs on a regular basis today when leases expire.

Consequently, there are several key distinctions between the jubilee and sabbath year stipulations. First, as already noted, jubilee debt would have involved more money than sabbath year debt. A somewhat arbitrary dividing line might be that jubilee debt would have been of a scope requiring more than an entire sabbath year period to repay.

Second, sabbath year debt had nothing to do with the land which was the inheritance. Whatever collateral was provided was relatively small and portable. In contrast, under jubilee debt, the land was the 'collateral'. However, since the 'lender' only bought the produce of the land for a period of time (up to the next jubilee) collateral is really an inappropriate term. Rather, under jubilee debt, the borrower ('seller')

75 This has caused some confusion. For example, Borowski suggests a maximum of 50 years overlooking the matter of sabbath year. His figure not only counts all seven sabbath years (during which there were no 'crops') but also the subsequent jubilee year (Borowski, Agriculture, 24). Rather, the range should from 1 to 42. Given that the last year before jubilee was a sabbath year, the latest one could 'lease' his land would be two years before the jubilee year with one year of crops, although it seems likely that in this case the preferred option would have been sabbath year debt. The earliest one could 'lease' his land would be the year after jubilee with seven sabbath fallow years, thus 42 crops.

76 Calum Carmichael, Illuminating Leviticus: A Study of Its Laws and Institutions in the Light of Biblical Narratives (Baltimore: Johns Hopkins University Press, 2006): 124. 
lost control of the land for a period of years (which meant loss of income) although in a legal sense the land was still his (or at least his family's). ${ }^{77}$

Third, under sabbath year debt, one option of repayment was 'debt slavery' where the debtor obligated himself to the lender for a period of up to six years to pay off the debt. Any debt that remained in the sabbath year was forgiven. Contrary to both Chirichigno and Baker, in the case of jubilee, there would have been no debt slavery since in reality there was no debt. The logic is very simple - the buyer had bought a commodity (a number of crops), which were delivered to him over the period of the lease. At jubilee, he had his full purchase and was owed nothing more.

\section{Servitude and Jubilee}

If this last point is correct, this raises a significant issue with the standard interpretation of Leviticus 25:35-40. For example, Hartley states, 'a brother may become so מוך, "poor", that he has to sell himself into servitude to another person' ${ }^{78}$ Kiuchi asserts that he becomes a slave. ${ }^{79}$ While this understanding seems to explain the phrase, 'he sells himself to you' in verse 39 , it is hard to reconcile with the subsequent statement in the same verse 'you shall not subject him to a slave's service'.

The most common way of handling this distinction seems to be to argue that what is being addressed here is a form of debt slavery as opposed to chattel slavery. Chirichigno takes this position and views the situation as a third step down in destitution with the distinction being that he is not to be treated like a chattel slave ${ }^{80}$ Kiuchi takes a similar view stating that this slave 'should not be treated as an ordinary slave' ${ }^{81}$ Milgrom agrees with Chirichigno's third step, but contrasts the situation as one where 'the Israelite slave is not a slave' but a hireling. This seems to be a step in the right direction, however, Milgrom still views the individual as indebted to his 'employer' and as one 'whose

\footnotetext{
77 Milgrom, Leviticus 23-27, 2217.

78 Hartley, Leviticus, 440.

79 Kiuchi, Leviticus, 462.

80 Chirichigno, Debt-Slavery, 351-52.

81 Kiuchi, Leviticus, 462.
} 
work amortizes the principal' ${ }^{82}$ While it does address the issue of phrase in Leviticus 25:39 'he sells himself to you', it misses the point of the land lease in which case there would not have been a principal to amortise. In this case, Baker is correct when he states 'Leviticus is not concerned with slavery at all.' 83

The tension here is the Hebrew root מכר (mkr), which normally means 'to sell'. In the Niphal stem, it is generally translated as a reflexive (so NASB, NIV, NRSV, and ESV). ${ }^{84}$ Lipinski argues that 'this verb does not apply specifically to the semantic field "buy/sell", but designates a delivery of goods ... with or without the intention of passing ownership' ${ }^{85}$

If correct, the question then would be what 'goods' were being delivered? Milgrom argues that it was just the labour of the Israelite, since an Israelite could not be sold. ${ }^{86}$ One problem with this view is the question of how does it relate to the jubilee land principle? Milgrom (following Japhet) sees this slave law as a mirror image of the land law: as only the produce of the land was sold, so only the labour of the worker was sold. ${ }^{87}$ However, this seems to depend on a subtle distinction in English translations of the Hebrew word 'ebed rather than a clear distinction between categories in the text.

It would seem that a better approach might be to begin with the question of what would the 'seller' live on subsequent to the 'sale'? One possibility is that he would have some of the cash that he had received from the lease of the land. With this, he might move into a city where he would ply another trade. Or, he may move to another country where he could either buy or lease land, or perhaps work another's farm. In any event, since the lease transpired because of financial need, it is unlikely that much money was left over after that need had been met, although that may have depended on the nature of the lease. If the lease had been negotiated for the entire period until the next jubilee, it is possible that part of the money met the need, and the rest provided living resources. Here, we also need to recall that

\footnotetext{
82 Milgrom, Leviticus 23-27, 2216.

83 Baker, Tight Fists or Open Hands?, 172.

84 Cf. GKC §51. While Baker notes the tension between the reflexive understanding and a passive (be sold), he argues that in reality, the issue is moot (Baker, Tight Fists or Open Hands?, 172, n. 126).

85 E. Lipinski, s.v. 'מכר (mkr)', TDOT VIII, 291-92.

86 Milgrom, Leviticus 23-27, 2217.

87 Milgrom, Leviticus 23-27, 2217.
} 
generally farmers in ancient Israel lived in settlements or villages and walked to surrounding fields. Thus it would seem that the living quarters would be unaffected by the lease, suggesting that the debtor likely would remain in his home, with the advantage of his existing social network.

It also seems probable that the length of the lease, the period of time to the next jubilee, is a maximum period (similar to what was suggested for sabbath year debt) with the actual term of the lease dependent upon the amount of money needed. Even in the former case, it is unlikely that adequate money was left for the 'seller' (who was leasing out his land) to live on until the lease was completed.

As noted above, Israelites lived in a village or settlement and walked to their fields. Hopkins suggests that each family would have several fields and for the purposes of diet and risk spreading would grow different crops in each field. ${ }^{88}$ It is then likely that in most cases of a jubilee type of land lease only a portion of the land would be leased out.

In conjunction with this, another possibility is suggested by the phrase, 'he shall be with you as a hired man, as if he were a sojourner' (Lev. 25:40). A sojourner, or resident alien, was an individual who had chosen to live in the land of Israel, but who was not an Israelite. As an alien non-Israelite there were social-legal obligations to which he would not be required to adhere, for example being circumcised (although in that case he would not be able to participate in the Passover [Exod. 12:48]). At the same time, there were other obligations that he would be expected to follow regardless, including some of the ritual purity requirements such as not eating blood (Lev. 17:12). But, there were also restrictions. According to the Old Testament law, as an alien, he would not be able to buy (i.e. own) any of the land which had been given to the nation of Israel as a national inheritance. Rather, any work he did would be as a hired hand. ${ }^{89}$

This would then suggest that Leviticus 25:35-41 provided a situation where the 'seller' could continue to work the land of his inheritance which he had leased out. However, rather than the harvest belonging to him, it would belong to the 'buyer' (i.e. the one who had leased the land). In return for his labour that produced the crop, the

88 Hopkins, Highlands of Canaan, 237-45.

89 Milgrom, Leviticus 23-27, 2221-22. 
seller would receive the normal wages of a hired hand..$^{90}$ As such, he would be receiving a portion of the harvest of the land that he was working (either as produce or as silver). Then, in the jubilee year, the usufruct of the land would return to his family. ${ }^{91}$

\section{Contrast between Jubilee and Sabbath Year Servitude}

Based on the above criteria, it is then suggested that the key difference between the service involved in the sabbath year servitude and the jubilee servitude was not whether the borrower was a land owner or not (in an agrarian society, almost all would be land owners). Rather, it lay in the size of the debt incurred, and how the borrower was expected to repay the loan. Under the sabbath year criteria, the land was not a factor. The borrower either repaid the debt in kind, or used labour (either his or that of a family member) to repay it. ${ }^{92}$

Under the jubilee criteria, the borrower's land was used as a means of generating income that went to the lender in the form of a lease. While it is suggested that the borrower might actually continue to work that land, it is not clear whether the lender would normally expect the borrower to do so, or whether that was merely one option. Regardless, if the borrower worked the land, his status was not to be viewed as that of a 'slave' but rather as a hired hand; that is, he had the same status of a resident alien who was not able to work his own land, and was to be paid for his labour. It would then be expected that he would return to a full 'ownership' (i.e. usufruct) of the land in the jubilee year. For this reason, a land 'sale' (i.e. lease) would be legally set up to reflect the next jubilee year which effectively put a decreasing cap on land 'values' (or lease amounts) as jubilee approached.

90 Milgrom, Leviticus 23-27, 2222-24.

91 One key point of confusion regarding the jubilee year is the idea that the land would be 'redistributed' (for example, see Lowery, Sabbath and Jubilee, 68-69). It cannot be stressed enough that jubilee was not a time of redistribution, but lease termination.

92 An interesting follow on to these criteria which this study does not address is that under sabbath year servitude the borrower had an option to continue in an 'ebed (servant/slave) relationship with the lender once his obligated service was completed. 


\section{Conclusions}

Overall, the issue of manumission of abadim demonstrates a tension between idealistic aspirations and realistic expectations. The canonical text asserts that the people of Israel had a God-given inheritance based on the premise that the entire land belonged to God, and the nation was his possession (Exod. 19:5; Lev. 25:23). As a result, the nation was told that if it listened to God, 'there will be no poor among you' (Deut. 15:4-5). Almost immediately afterward, however, the assertion is made that 'the poor will never cease to be in the land' (Deut. 15:11).

While the text anticipates that the nation would fail to adhere to the covenant, various safety nets were provided. One safety net governed borrowing from other Israelites with several options to repay, even including servitude. Another safety net was the provision that an Israelite could lease out (as opposed to sell) the land of his inheritance in cases of significant financial need. In both cases, guidelines were given to ensure that the safety nets did not become snares. In the case of borrowing, it was the remission of short term debt and manumission of debt slavery in the sabbath year. In the case of a land lease, it was directed that the land which had been given as part of the national inheritance could not leave the family, and use of the land returned to the family in the jubilee. The understanding of these safety nets presented in this study suggests that they were strong with significant flexibility to accommodate a variety of situations - if they were observed. Whether observed or not, the overall purpose was to ensure that each generation would have the basic capital assets needed to make a living so that the nation would not develop a permanent landless indigent class - if the nation obeyed God. 